\title{
Stakeholders' engagement platform to identify sustainable pathways for the development of multi-functional agroforestry in Guadeloupe, French West Indies
}

\author{
Carla Barlagne (D) Marie Bézard • Emilie Drillet • Arnaud Larade • \\ Jean-Louis Diman · Gisèle Alexandre $\cdot$ Arsène Vinglassalon • Maria Nijnik
}

Received: 20 January 2020/ Accepted: 19 July 2021 / Published online: 2 August 2021

(C) The Author(s) 2021

\begin{abstract}
Social innovation is critical in shaping human-forest relationships and how farmers and scientists engage with each other to design sustainability transitions. This paper reports on the outputs of a participatory stakeholders' engagement platform that was designed to draw on local farmers' knowledge and experience in identifying sustainable pathways for the development of multi-functional agroforestry in Guadeloupe. Two participatory
\end{abstract}

Supplementary Information The online version contains supplementary material available at https://doi.org/10.1007/ s10457-021-00663-1.

C. Barlagne $(\bowtie) \cdot$ M. Nijnik

Social, Economic and Geographical Sciences Group, The James Hutton Institute, AB15 8QH Aberdeen, Scotland e-mail: Carla.Barlagne@hutton.ac.uk

M. Bézard · E. Drillet · A. Vinglassalon SYAPROVAG, 97170 Petit-Bourg (Guadeloupe), France

A. Larade

Parc National de Guadeloupe, 97120 Saint Claude, Guadeloupe

J.-L. Diman

INRAE UE PEYI, Centre Antilles Guyane, Domaine de Duclos, Prise d'Eau, 97170 Petit-Bourg (Guadeloupe), France

G. Alexandre

INRAE URZ, Centre Antilles Guyane, Domaine de Duclos, Prise d'Eau, 97170 Petit-Bourg (Guadeloupe), France workshops were organised that aimed to gain insights into the reality faced by farmers, in particular: (i) their vision of the future, needs and aspirations; (ii) their understanding of barriers and enablers in relation to the sustainability challenges they are confronted with and; (iii) their framing of human-environment relationships in socio-ecological systems. Outputs of the activities were synthetized by the research team and represented graphically for analysis. Results show that while farmers envision prosperous multifunctional forest farms in the future, they have to face complex challenges that require solutions at multiple scales and suggest different types of innovation: social, institutional, market-based and technical. Farmers saw themselves as being part of the socio-ecological system and as custodians of the natural environment. We discuss the implications of those results in the context of the absence of a system of innovation for agroforestry in Guadeloupe and highlight the opportunity for a innovation ecosystem thinking approach that integrates better the agricultural and forestry sectors, but also between actors and scales of governance. Implementation of a Stewardship status would enable farmers achieve their vision and embrace a custodian role vis-à-vis the agroforest. Embededment of the stakeholders' engagement platform and its enabling processes in the innovation ecosystem is key to achieve those objectives. 
Keywords Social innovation - Socio-ecological system · Innovation ecosystem · Guadeloupe · Vanilla $\cdot$ Biodiversity

\section{Introduction}

Forests provide a range of ecosystem services that sustain rural livelihoods and well-being (MEA 2005; Sunderlin et al. 2005). While pursuing livelihoods is a necessity for forest dependent communities (Nijnik et al. 2019), concerns have been raised as to the impact of human activities on natural ecosystems and their components (Power 2010). Human-forest relationships are often shaped in terms of opposition, and relationships between livelihoods and biodiversity conservation seen as antagonistic (Adams et al. 2004; Persha et al. 2011), therefore contributing to social and environmental conflicts. This is because the intensification of food production over the past century to a large extent has been at the expense of trees (Foley et al. 2011; Power 2010). Another reason is that agriculture and forestry tend to be managed in a sectoral way, with sometimes competing objectives. The prevailing framings tend to overlook potential synergies and consider food production and biodiversity conservation 'individually' (Glamann et al. 2017), while potential synergies between biodiversity conservation, forestry and food production need to be accounted for (Minang et al. 2014; Sayer et al. 2013; Sunderland et al. 2007). Agroforestry is a form of integrated land management that combines agriculture and forestry on a same unit of land and aims to "create environmental, economic, and social benefits' (USDA 2019). Forest farming is one type of agroforestry practices and refers to growing non-timber forest products (food, herbs, botanical or decorative crops) under a forest canopy 'that is managed to provide ideal shade levels as well as other products' (USDA 2019). It is the type of agroforestry practices discussed in this paper.

To address synergies between rural livelihoods, biodiversity conservation and the capacity of the natural environment to provide ecosystem services, the role of local communities is central (United Nations Development Programme 2015). Local participation in forest governance is considered a 'key mechanism' to incentivise communities to use resources in a sustainable way (Agrawal et al. 2008; Larson and Soto 2008). Also, by taking an active role in the management of natural resources, communities enhance their knowledge, feel accountable and therefore can perceive forest rules as being more legitimate (Larson et al. 2008). They re-invent their traditional roles and capacity to innovate (Nijnik et al. 2019), therefore improving the delivery of sustainable, smart and socially innovative solutions (Khadka et al. 2018). But if stakeholders' inputs into the use and management of natural resources is crucial, their participation in framing problems and identifying solutions to be implemented is even more relevant and potentially powerful.

Communities' participation in tackling challenges has been widely studied in environmental management (Prabhu et al. 2012; Reed 2008) and agricultural research and development (de Souza et al. 2012; Schut et al. 2015; Scoones and Thompson 2009). While the environmental management literature focuses on management and governance, the agricultural research and development literature focuses on understanding the uptake and diffusion of innovation. Both streams acknowledge the value of communities' participation and the evolution of approaches to participation: (i) from top-down to bottom up approaches; (ii) increased inclusion of stakeholders' voices at different stages including from the outset. As stakeholders' participation increases awareness of the multiple dimensions of a problem, it also provides insights into the feasibility, socio-cultural and economic adequacy and acceptance of potential solutions (Faysse 2006). In that sense, stakeholders' contribution to the analysis of a situation is perceived as critical.

More recently, social innovation has been identified as crucial for addressing challenges (BEPA 2012) as it has the potential to deliver tangible and positive benefits for rural communities (Neumeier 2012; Smith and Seyfang 2013). Social innovation refers to the reconfiguration of social practices and new institutions such as networks, partnerships, collaborations and governance arrangements-in response to societal challenges and opportunities (MacCallum et al. 2016; Polman et al. 2017). Its potential lies in offering 'new ways of framing, knowing, doing and organising' (Haxeltine et al. 2016) and transforming the way researchers, development agents and rural stakeholders usually work together. It represents a shift in the perspective and approach to development that 
provides opportunities for better inclusion of stakeholders' voices, values and vision in matters that concern them and for valuing their experience (Bock 2012).

Innovation actions aim to enhance social innovation. They are user-centred action arenas aiming to accompany social innovation actors in the definition and realisation of their objective (Govigli-Marini et al. 2020). They create collaborative learning and networking, with continuous interactions among researchers, knowledge brokers and rural stakeholders to foster and mainstream innovations and leave a durable legacy (SIMRA 2016). The framework underpinning innovation actions Govigli-Marini et al. (2020) proceeds through three phases of design, implementation and consolidation.

The rationale of this study is to understand the challenges brought about by pursuing multiple objectives in a forest landscape (i.e. fulfilling livelihoods, ensuring the protection of the environment and ensuring biodiversity conservation) by giving a voice to its primary users.

We applied our analysis to the forests of Guadeloupe, an overseas region of France in the Caribbean. Until the 1950s, agroforestry practices have shaped the mountainous forest landscape and contributed to sustaining the territory with forest's resources such as wood and food (i.e. seeds, coffee, vanilla, cocoa, fruits, tubers). Subsequent development of the Guadeloupean agriculture progressively led to the decrease of the agrobiodiversity of those systems and agroforestry practices were mostly abandoned in the 1970s in favour of a type of mechanized, export oriented and productivist agriculture developed in the lowlands. As a consequence, the high value added crops (ie. coffee, cocoa, vanilla) and the subsistence oriented crops cultivated in the upland agroforestry systems either became a negligeable part of the agricultural production or were relegated to landscape interstices. Since the 1990s, agricultural development programs have attempted to revive traditional agroforestry practices by adopting sectorial approaches, focused on the development of a single crop (i.e. vanilla or coffee or cocoa). So far, the succes of those different programs in sustaining the development of agroforestry has been mixed. This study aims to contribute to a roadmap for agroforestry in Guadeloupe by outlining the sustainability challenges faced by vanilla forest farmers and identifying sustainable pathways for the development of multifunctional forest gardens in Guadeloupe. To achieve that objective, we draw on local farmers' visions, values, knowledge, and experience. In particular, we built upon the framework proposed by Govigli-Marini et al. (2020) (the first step or design phase in particular) to set up a participatory process and gain insights into: (i) farmers' vision, needs and aspirations for the future; (ii) their understanding of barriers and enablers in relation to the sustainability challenges and (iii) their framing of human-environment relationships in socio-ecological systems and how those inform priorities for research and development of multi-functional forest gardens in Guadeloupe.

This work adds to current literature on multifunctional agro-forests, human-forest interactions, on the role of social innovation both in designing sustainability transitions and in evolving approaches to participation by providing evidence from a marginalised rural area. Our paper reports the outputs from the developed participatory processes and explains how they inform innovation pathways for agroforestry in Guadeloupe.

\section{Material and methods}

The case study and study area

Guadeloupe is an overseas region of France in the Caribbean (Fig. 1). The Archipelago of Guadeloupe is $1,628 \mathrm{~km}^{2}$ and is one of the 34 Hotspots for Biodiversity in the World (Myers et al. 2000).

The Agricultural Union of Vanilla Farmers (50 members of which 30 active) in Guadeloupe called SYAPROVAG was created in 1993 to revive this historical crop. Up to $35 \mathrm{t} /$ year of black vanilla used to be produced until the 1920s in Guadeloupe while current production currently hardly reach $1.5 \mathrm{t} /$ year (SYAPROVAG, personal communication). Official agricultural statistics about the sector are scarce to inexistant given its confidentiality. Vanilla, as a perennial forest production, is very sensitive to climatic hazards and has a long period of return on investment (SYAPROVAG, personal communication). This can lead to farmers having a negative cashflow for several consecutive years. Guadeloupe counts with 71, 000 ha of forest of which over half is private. Public forest is mostly managed by a state 


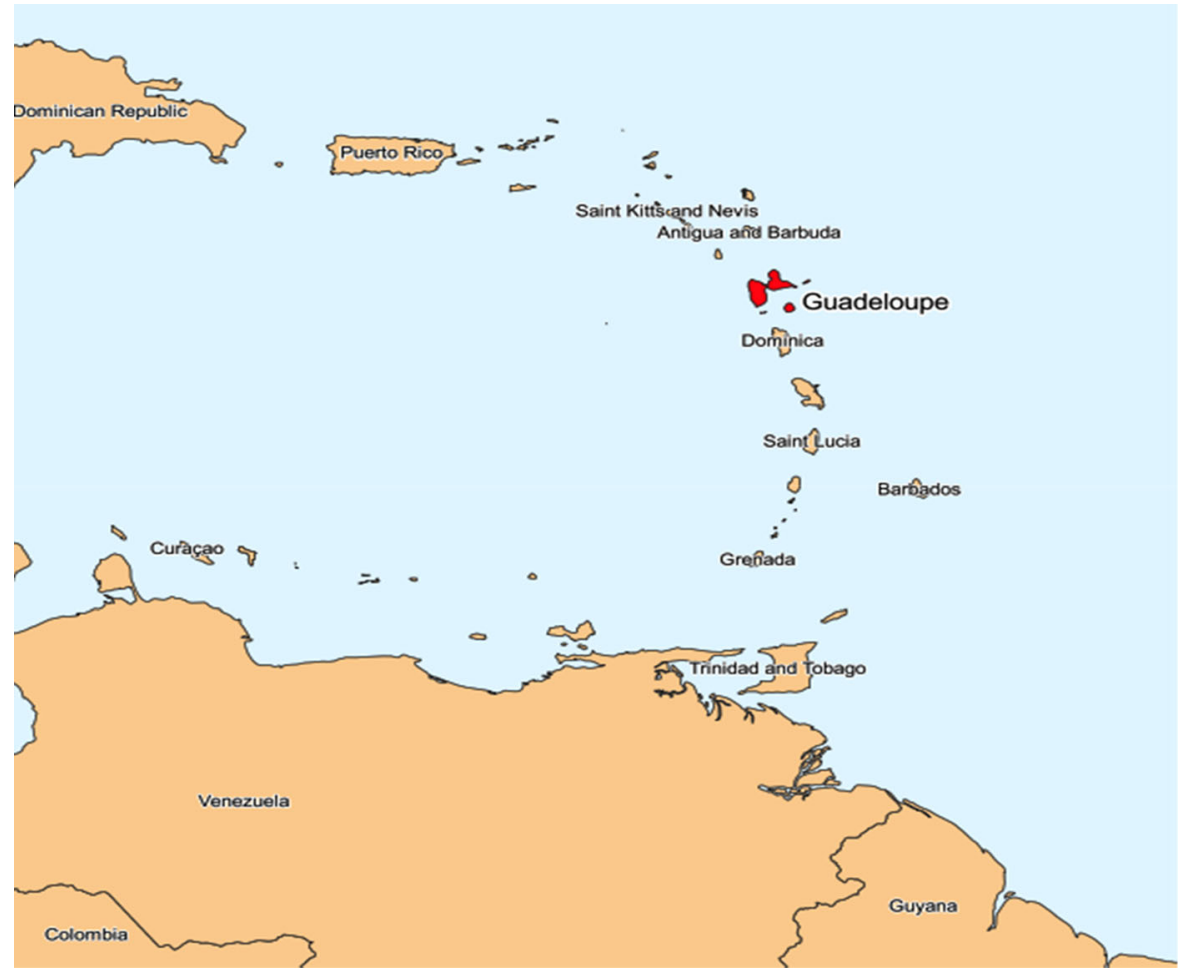

Fig. 1 Location of the study area. Map made with Natural Earth. Free vector and raster map data @ naturalearthdata.com

agency - the National Forest Office-under specific regulations which are beyond the scope of this paper. The case study presented in this paper concerns mainly privately owned forest, the majority of the SYAPROVAG members and participants to the workshops, being private owners.

The VALAB operational group (OG):

an interdisciplinary stakeholders' platform led by a farmer organisation

In 2011, having experienced the lack of sustainability of vanilla production, the SYAPROVAG formulated the hypothesis that diversifying the production could be a solution to the lack of sustainability of forest vanilla production. In 2016, the SYAPROVAG created the VALAB operational group (OG) to test this hypothesis and formulated the VALAB concept that stands for: Integrated Value Enhancement of the Guadeloupean Forest Agrobiodiversity (in French: Valorisation Ecosystémique Intégrée de l'Agrobiodiversité de la forêt de Guadeloupe). Funded by the Measure 16.1 of the European Agricultural Rural
Development Fund (EARDF) for the emergence of operational groups, the OG was organised in 2018 within the European Innovation Partnership (EIP) with the objective to test the ecological, economic and social sustainability of diversification of agricultural production in the forest through forest farming. In the introduction, we have defined agroforestry and forest farming. Forest farming is currently the specific type of agroforestry the VALAB OG focuses on, given that it is the practice most of the members of SYAPROVAG have adopted. In the remainder of this article, we will use the term 'agroforestry' to refer to the general land use management practice and to 'forest farming' when referring to the specific case of the VALAB OG or the farmers of SYAPROVAG. We also refer to 'forest garden' as the agrosystems resulting from forest farming and to 'forest farm' as the economic, social and environmental unit supporting forest farming. The OG is composed of the partners of the project. Operational groups are plebiscited by the European Union to encourage bottom-up initiatives with a strong problem-solving and placed-based development focus. As an interdisciplinary platform, the OG counts 


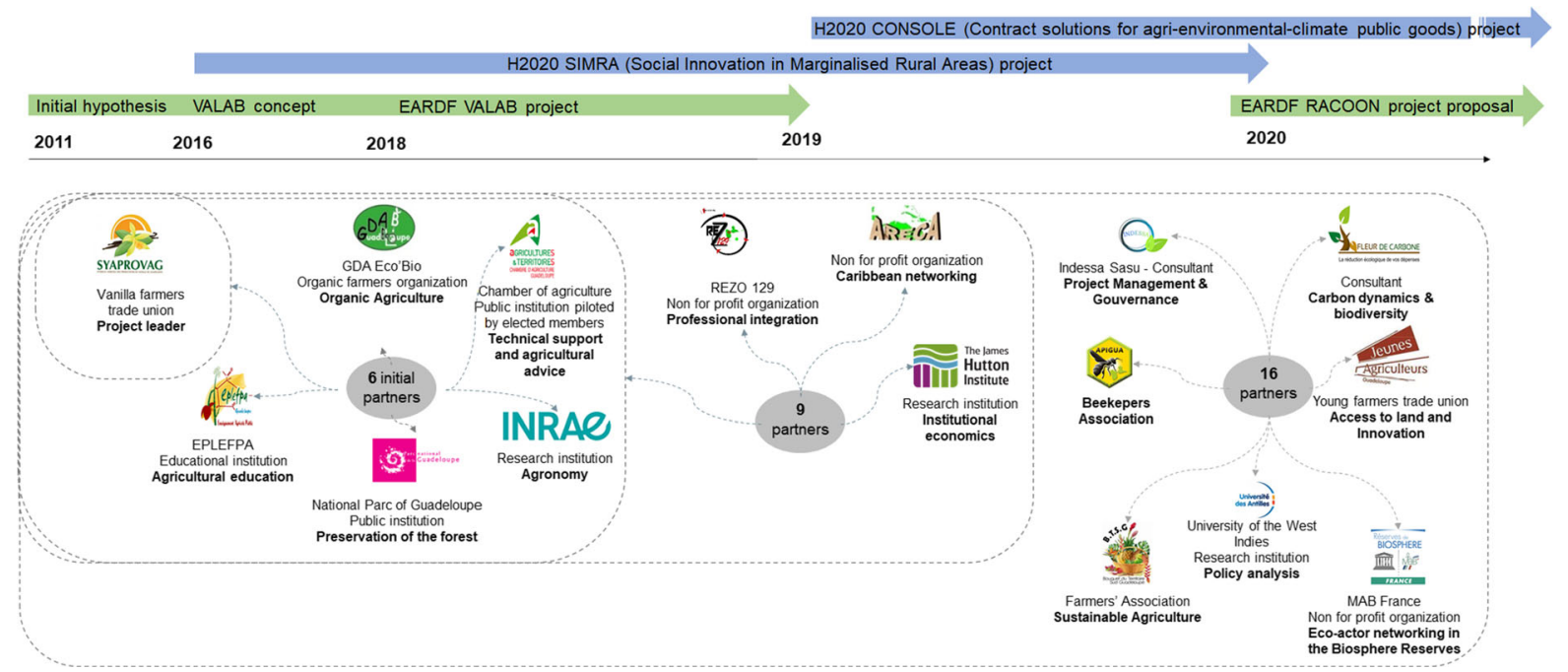

Fig. 2 Evolution of the VALAB operational group (OG) from the initial hypothesis formulated in 2011 to the current partnership. Initially formulated by a core group of 3 farmers, the hypothesis of the diversification of the production of forest gardens became the VALAB concept in 2016. The OG, of the

with a range of partners with complementary skills, expertise and mandates (ie. farming, agronomy, ecology, economy, education, social, research, extension, consulting, solidarity and insertion, nature conservation). Those members belong to the private, public and non-for-profit sectors (see Fig. 2).

Beyond the VALAB project, the OG has contributed to European projects such as the Horizon 2020 SIMRA and CONSOLE projects. Activities developed in those projects are complementary to those run by the OG while expanding their scope. By contributing to those projects, the $\mathrm{OG}$ is able to benefit from and contribute additional expertise and collaborative opportunities. The day to day functioning of the $\mathrm{OG}$ is dependent upon targeted funding available through the European Agricultural Rural Development Funding (EARDF) without which, its activities are limited. The VALAB project was funded by the EARDF for one year. It led to the establishment of the OP and a baseline study of current forest farming practices. The RACOON project proposal, submitted in 2020, aimed to follow up on the activities started in VALAB. same name was created in 2016 and counted with 6 partners. It has since then expanded, and now counts with 16 partners that aim to test the hypothesis and have been developing project proposals for that purpose. Expertise and mandate of the partners are indicated in bold

The participatory workshops: towards a shared vision of the multifunctionality of the forest

Two participatory workshops were organised as part of the Horizon 2020 SIMRA project, in coherence with the objectives pursued by the operational group ie. the workshops aimed to create a shared vision of the multifunctionality of the forest amongst members of the OG. Each workshop focused on a specific theme developed in the next two sub-sections. The workshops' outlines were developed with inputs from the core members of SYAPROVAG both in terms of the objectives and design. This approach took into account the experience and expectations of the core members of SYAPROVAG vis-à-vis the wider network of members (50 members) but also aimed to empower them to take ownership of the process. The activities were conceived so that both their structure and content created the conditions for social learning, human and social capital reinforcement and tangible outputs delivery. Recruitment of participants was conducted by the SYAPROVAG who invited their current and prospective members with a view to include women and young farmers. 4 women and 14 men attended the workshops and 6 participants were below 40 years old ( 1 women, 5 men). 17 of the farmers owned private forest and 1 of them rented public land from the 
National Forest Office. This farmer was included due to his membership to SYAPROVAG. Albeit with a different landownership status, he shared part of the constraints highlighted by private owners.

Understanding farmers' vision for the future and barriers and enablers in relation to sustainability challenges: workshop 1

The first workshop was attended by 17 participants and 6 facilitators. It aimed to understand the challenges faced by farmers, identify their needs in respect to those challenges as well as potential solutions. The workshop plan was to lead the participants to envision a trajectory from their current situation to a future desired situation (Prabhu et al. 2012). The current situation was presented as the following 5 types of existing production systems (Castro Nunez 2018): (1) Heritage crops and tourism activity; (2) Heritage crops outside the woodland; (3) Heritage crops on land managed by the Office National des Forêts ${ }^{1}$ (ONF); (4) Heritage crops in private forest; and (5) Forest gardens. Participants were asked to identify which type they belonged to, to reflect upon this typology and add the criteria they thought were missing. They were then asked to reflect upon: (i) the futures they desired in 10 years' time; (ii) barriers that could prevent them from achieving this vision and; (iii) possible solutions that could be implemented. A problem-action matrix (Hewitt et al. 2017) map out potential barriers that comprised two axes: (i) the type of problems or constraints faced (technical, organisational, commercial, legal/regulatory and environmental) and (ii) the level at which this constraint occurred (individual, collective or at a larger scale linked to the wider socio-institutional system).

Problems were prioritized by means of a vote using sticky dots. Each participant was given 5 sticky dots that they had to position on the problems they thought needed to be prioritised. Problems were ranked according to the number of dots they gathered. In each group, participants were paired and asked to define corresponding solutions by identifying: (i) what needed to be done; (ii) how; (iii) who had to be involved and in what capacity (Who does? Who

\footnotetext{
${ }^{1}$ The National forest office is a French governmental agency in charge of the management of state forests, city forests and biological reserves.
}

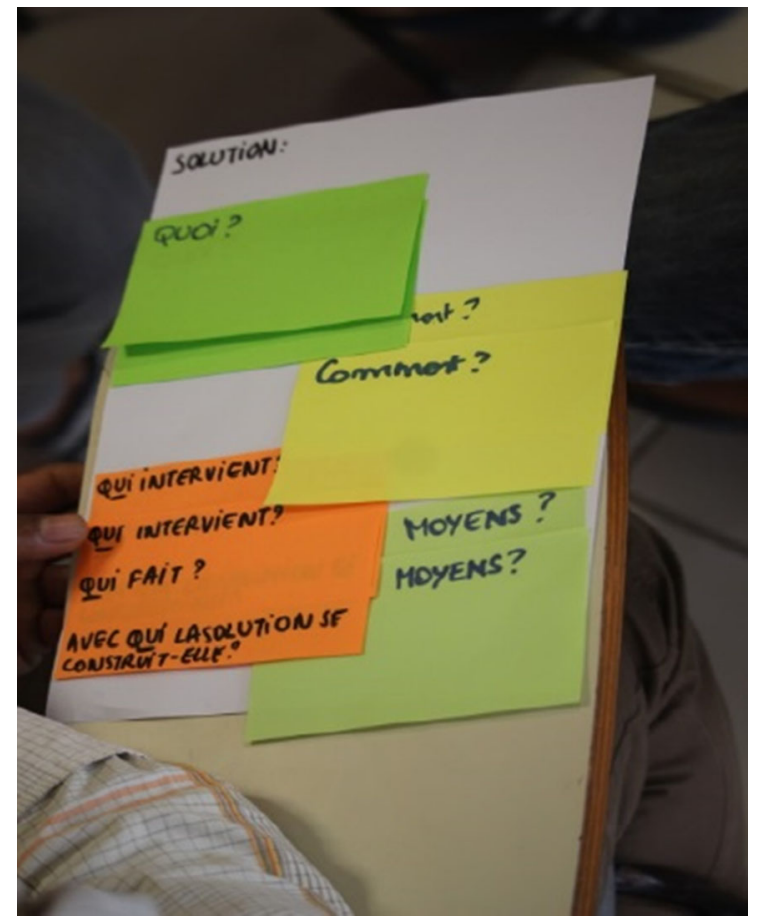

Fig. 3 Unfolding solutions

intervenes? With whom does the solution has to be constructed?) and (iv) the means necessary to implement the solution (Fig. 3). Answers to those questions helped the participants identify the steps they needed to implement to achieve the desired future and shape the trajectory towards this future. Due to time constraints, the participants and facilitators reflected on the first 10 problems identified.

The solutions found in the two groups were discussed in the plenary session. Both groups had the opportunity to comment on each other's solutions. Results were summarized by the team of facilitators and a participatory evaluation of the workshop was organised. A debating time was included for participants to reflect on the two days' workshop.

Understanding farmers' framing of humanenvironment relationships in socio-ecological systems and the role they want to play in those relationships: workshop 2

The second workshop was attended by a total of 18 participants, most of them returning from the first workshop. Activities aimed to assess the perceptions of the ecosystem services and biodiversity associated 


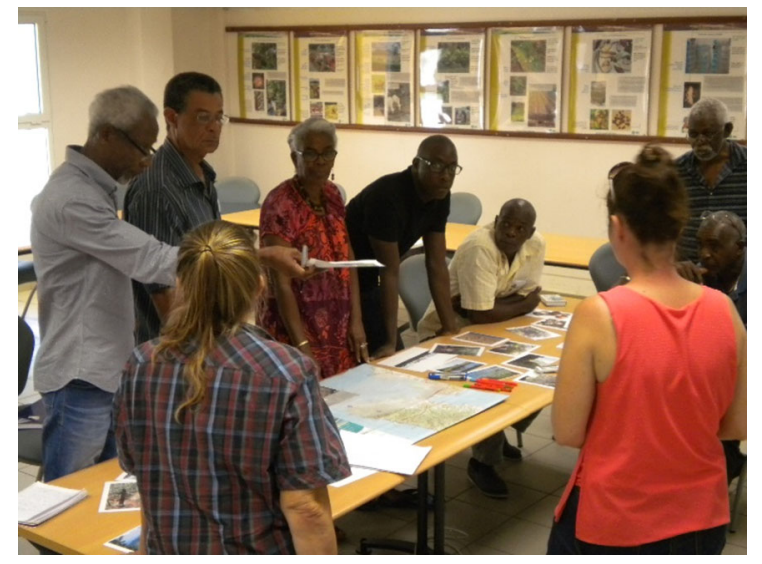

Fig. 4 Participants discuss landscape's elements, ecosystem services and biodiversity in the territory

with the forest and discover what farmers considered a heritage they wanted to pass on to future generations (Fig. 4). Heritage, ecological continuity and solidarity were the key themes discussed. The scale was territorial, and the workshop was facilitated by two pairs of expert-facilitator with ecological expertise and knowledge of the territory. Each pair interacted with a sub-group of participants. Participants were reminded of the historical dimension of forest farming based on Castro Nunez (2018). Pictures of the territory with landscape's elements, biodiversity, and ecosystem services were used to support discussions (Fig. 4).

In both workshops, activities were designed to support plenary's and sub-groups' dynamics, where deliberation processes took place, as well as to ensure that participants exchanged views between each other and facilitators who responded to participants inquiries, adding knowledge and sending back questions. Participants were asked to synthetize each activity and asked to feed them back during plenaries enabling them to be active in the learning processes and debates. The information collected was compiled and graphically represented by the research team.

\section{Results}

Current situation and desired futures

Findings from the first workshop indicate that half of the participants (identified as Group 1 for the subsequent activities) belong to types (1) Heritage crops and a tourism activity, (2) Heritage crops in the woodland and (3) Heritage crop on land managed by the ONF, while the other half (Group 2) belong to both types of (4) Heritage crops in private fores and (5) Forest Gardens of the Castro Nunez (2018)'s typology (Fig. 5). One participant stood out from the others by not owning any land, and therefore belonging to none of the types. This participant was assigned to Group 1, since his situation was similar to that of participants owning forest land, but not currently using it. Most of the participants stated that they were underusing the land because of the damage caused of the hurricane Maria in 2017. The two groups were then led to reflect separately upon their desired future.

Participants' current situation was contrasted with their desired future in the sense that all envisioned very productive farms (Fig. 5). The desired future in Group 1 corresponded to farms which would have 'optimized' the production of heritage crops and honey in 10 years. By 'optimization', participants referred to increased production (through increased yield and cultivated area) as well as better technical management of the crop and transformation processes. The desired future in Group 2 corresponded to moderately diversified forest gardens. After this step, some participants from both groups envisioned diversifying into agrotourism and/or educational farms. 7 participants out of 17 from both groups envisioned agrotourism and/or educational farms as their desired future. The trajectories to achieve desired futures comprised such steps as the acquisition of private land; production diversification; agro-processing and commercialisation of the production (direct sale).

Barriers to achieving desired futures

At total of 31 barriers belonging to the following categories were identified: technical, environmental, technical and organisational, legal and regulatory, commercial and others Fig. 6. Number of votes for the different problems identified were expressed either at: (i) the individual; (ii) collective or (iii) higher level (Fig. 7). Most of the constraints were expressed at the individual level followed by constraints at the collective level.

Technical barriers expressed at the collective level were the loss of knowledge and know-hows and the lack of technical references regarding forest farming. Legislative and regulatory constraints at the individual 


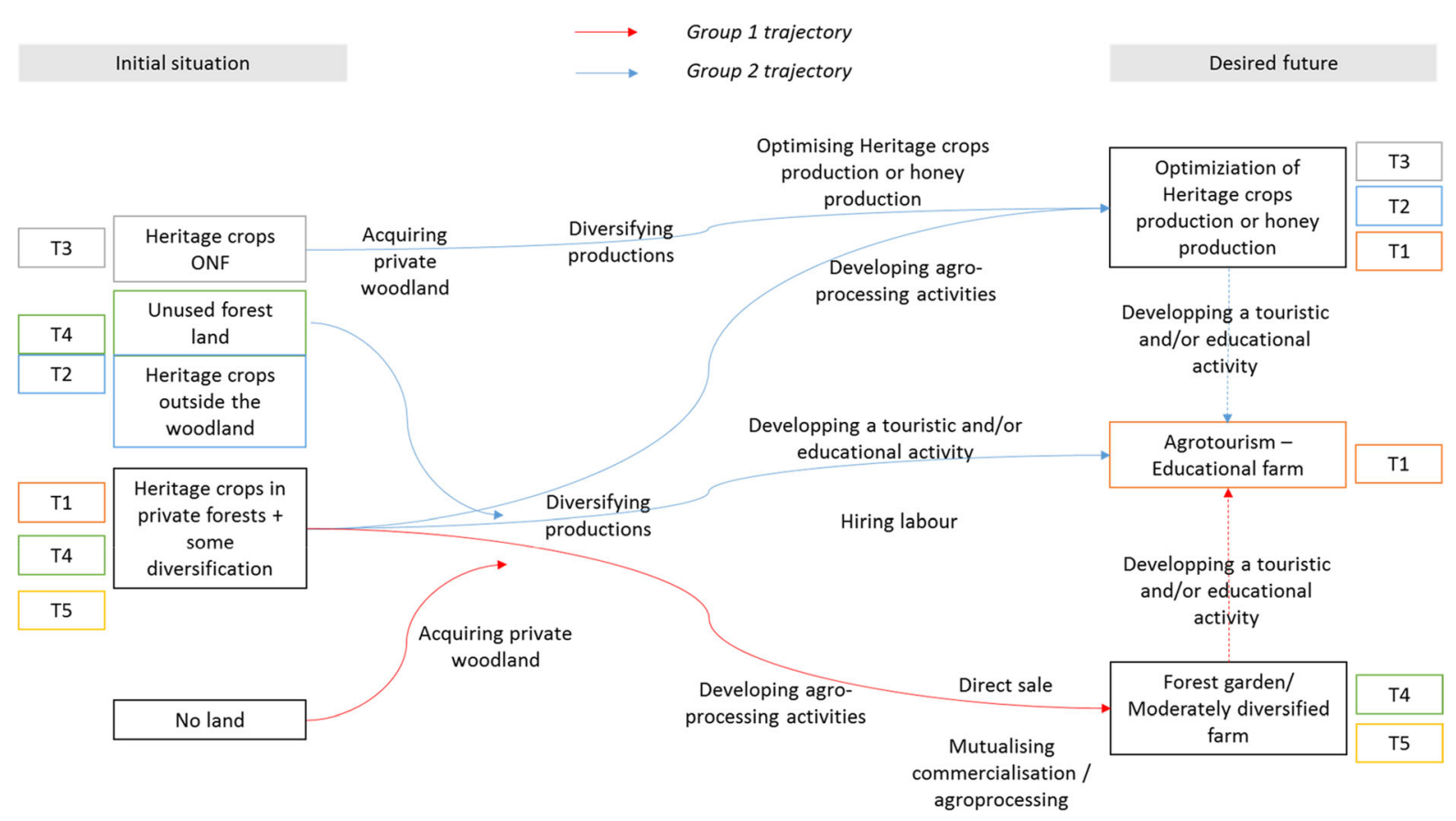

Fig. 5 Farms' trajectories towards the desired future (T1, T2, T3, T4 and T5 refer to the types of the typology by Castro-Nunez 2018)

level were the administrative burden and insufficient knowledge of the legislation. At a higher level, legislative and regulatory constraints identified were the lack of common interpretation of the legislation as well as remote and inaccessible state services. Commercial barriers at the collective level were the lack of market opportunities and of visibility of the production in forest farming. Natural constraints at the individual level were the difficulty to access forest plots and their remoteness. Organisational barriers at the collective level were the lack of collective organisation for on-farm work and inputs. Finally, 'others' refer to a wider range of barriers that could not be classified in any of the previous categories.

The first 10 problems prioritized were: the absence of technical references, of cash-flow and of adapted mechanisation, difficult access to plots, robbery and deterioration of the crops, hurricanes, lack of labour and of its collective organisation, loss of know-how and shortage of commercial opportunities. Those problems occurred at the individual and collective levels as well as at a larger scale related to the sociotechnical and institutional environment.
Solutions

Figure 8 represents the farmers' mental map of the solutions to achieve their desired futures. As revealed in the previous exercise, farmers envisaged diversification and optimization of production. To achieve this, 9 types of strategies were identified. The first one related to the production aspect and aimed to address the lack of knowledge and technics by creating sociotechnical references, maintaining existing knowledge and know-how and adapting mechanization. Solutions envisioned were: (i) assessing what exist in terms of knowledge and know-hows, (ii) adapt existing knowledge and technics, (iii) test and evaluate innovative systems and technics, and (iv) ensure that the knowledge and technics acquired are passed on to end-users. The second one related to a more collective organisation of the work and aimed to address the shortage of labour and difficulties to access adequate equipment. Solutions envisioned were: (i) to liaise with the third sector (i.e. non governemnetal and non-profit organisations) to implement social farming activities, (ii) revisit a traditional form of collective work on a farm labelled as 'lend-a-hand bank' and (iii) create a cooperative to purchase collectively and access costly 
Fig. 6 Number of votes for the different problems identified

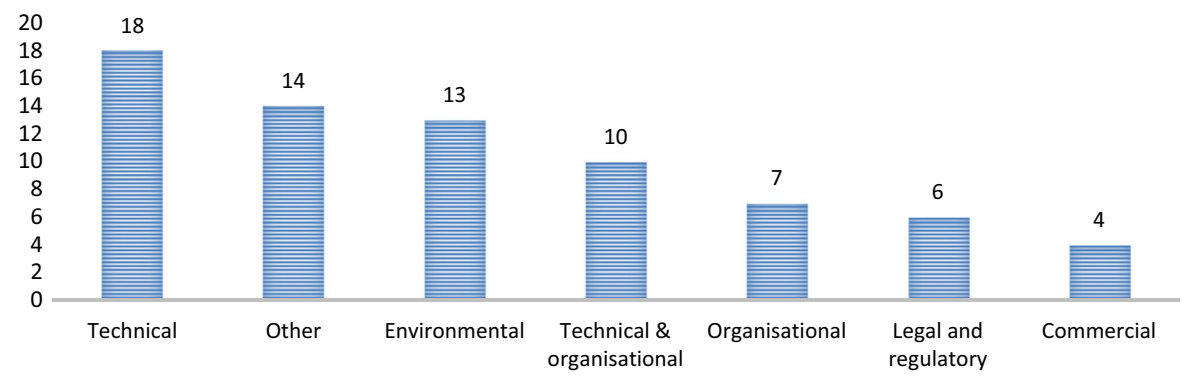

Fig.7 Number of votes for the different problems according to the level at which they occur

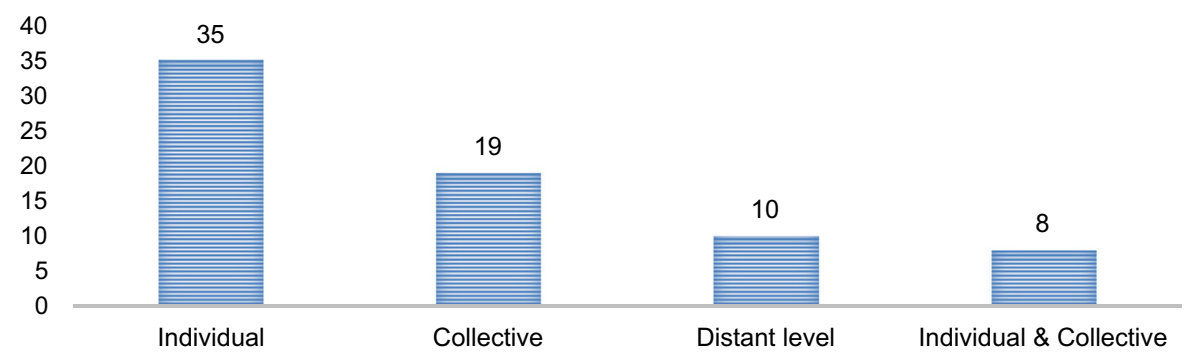

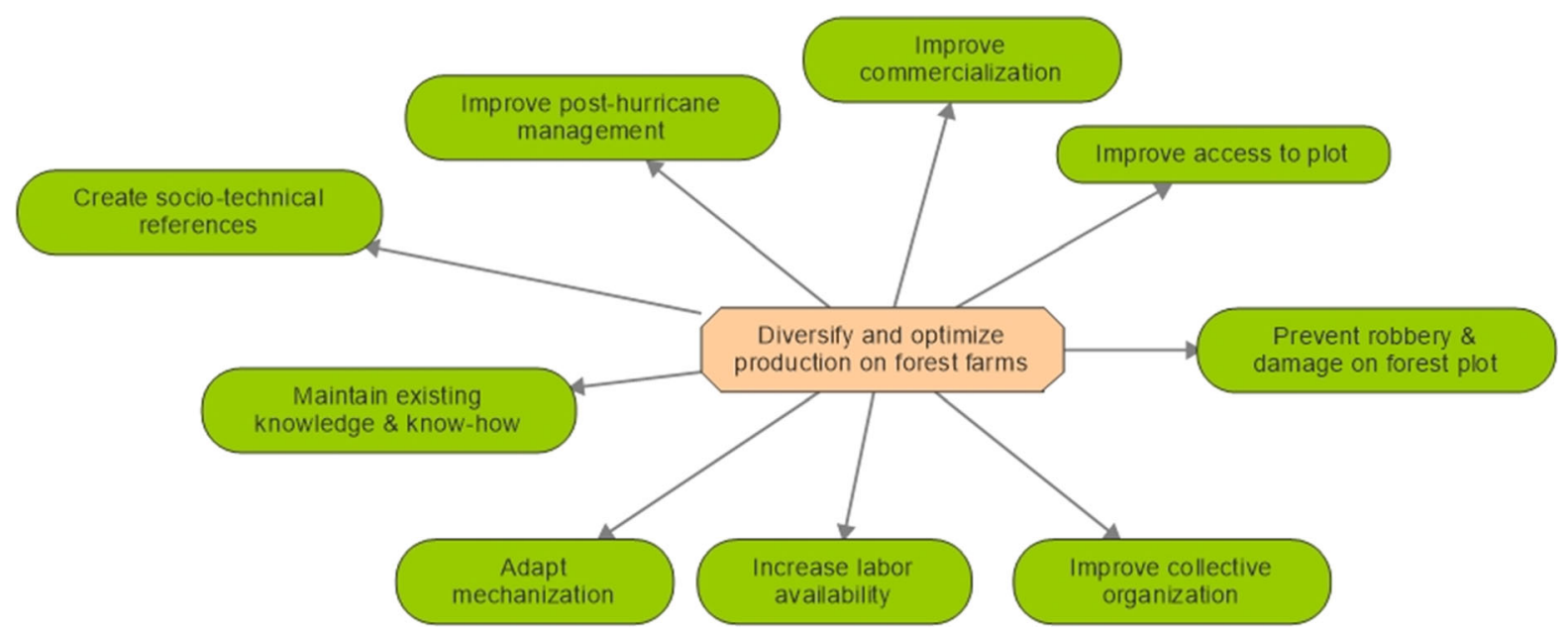

Fig. 8 Extract of the mental map of the solutions identified by the farmers to overcome barriers to achieve their desired future. The central item is the problem formulated, the green items are

agricultural equipment. The third one aimed at maintaining or improving the assets base by improving access to the plots, securing the plot to prevent robbery and damage and improving disaster management. Solutions identified were: (i) implementing peersurveillance, (ii) restraining physical access and (iii) marking vanilla pods to ensure that the owner is identified, and illegal trade does not occur. The last strategy identified was to improve commercialisation prospects by (i) increasing the quality of the product the strategies identified. Operational solutions for each strategy are described in the text. Full map available in supplementary materials. Graphics program: Mindmanager@

and targeting high-end markets, (ii) highlighting the distinctiveness of the product and adding value through labels and (iii) retaining most of the value by selling it directly to customers. Strategies were connected to each others, since some solutions fuelled several strategies (i.e. social farming or 'lend-a-hand' banks). Also, even if not represented on the map for the sake of clarity, the improvement of collective organisation would have beneficial effects on all strategies identified. 


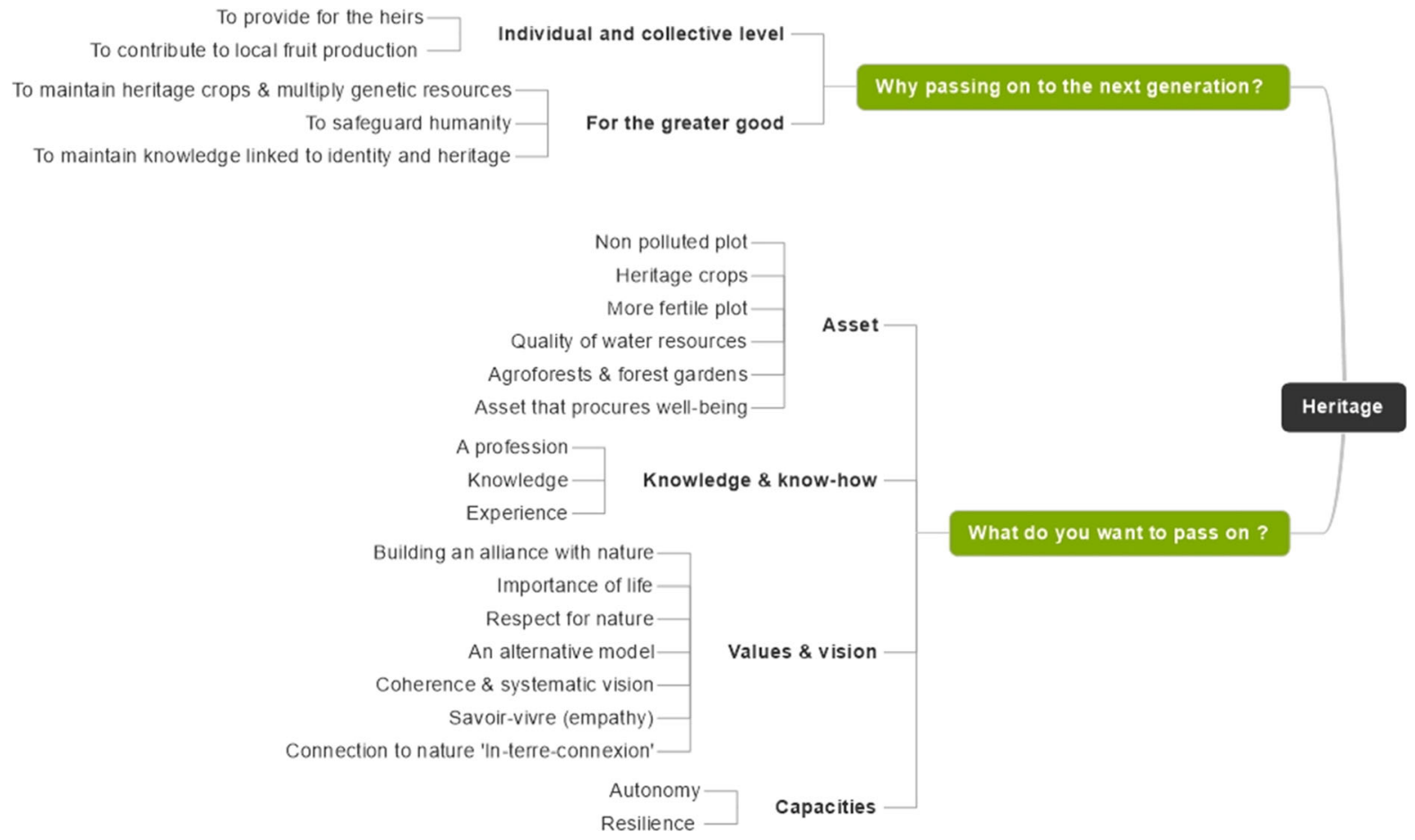

Fig. 9 Extract of the mental map of what Heritage meant for the farmers and what they wanted to pass on to the next generations. Full map available in supplementary materials. Graphics program: Mindmanager (c)

\section{Heritage}

In terms of heritage, the participants distinguished between the asset, the knowledge and know-how and the values and vision they have inherited (cf. Fig. 9 and supplementary materials). The asset was characterized in terms of its land tenure (family plot or concession plot), functional status (fertile soil), structure (creole garden ie. a traditional farming system characterized by the association of multiple crops in space and time), the Heritage crops (ie. the genetic material that can be found in the forest amongst which vanilla) and fauna it contained as well as less tangible aspects, such as a good quality of life. The knowledge and know-hows related to agriculture and ecology, and to practices related to the natural species and crops but also to the management of the cropping system, as well as soil fertility.

Changes that have occurred in relation to the asset consisted of: (i) improving its structural (drainage, access) and production capacity (e.g. rehabilitation); (ii) providing services (e.g. habitats for pollinators); (iii) changes to improve and diversify cropping practices (e.g. vanilla looping \& mulching); (iv) values and vision. Participants wanted to pass on (i) an asset that is able to procure human well-being; (ii) knowledge and know-hows; (iii) values and vision (e.g. respect for nature) and; (iv) capacities (e.g. resilience) (Fig. 9). They did not want to pass on: (i) practices that could have a negative impact on ecosystems; (ii) a polluted asset; (ii) negative values and vision. Finally, the reasons for what farmers wanted to pass on their heritage related to concrete objectives at the individual or collective levels and concerns over preservation of the common good.

Pathways to the sustainable development of forest farming in Guadeloupe

The outcomes of the workshop were integrated into a roadmap for the development of sustainable forest farming in Guadeloupe. The central idea of this roadmap is to establish the multifunctionality (environmental, economic and social) of the forest as a common good that has to be preserved while achieving the joint objectives of agricultural production and protection of the natural environment. This action strategy holds seven main pathways: (1) Recovering 
and capitalising traditional knowledge and knowhows associated with forest farming; (2) Producing technical references for forest farming through the characterization of the natural environment and its ecosystem services, assessing the potential impact of farming practices on the environment, identifying options to mitigate the environmental impact of agricultural practices on the forest ecosystem and experimenting in-situ innovative farming systems; (3) Transfering knowledge though the co-conception of experimental forest gardens, fostering peer-to-peer learning and elaborating adequate training for new entrants in forest farming; (4) Assessing conditions for the development of forest farming at the institutional level and public policies level by examining trade-offs and synergies offered by current governance arrangements and policy instruments as well as proposing innovative instruments and incentives for sustainable forest farming; (5) Fostering the creation of added value on forest farming products by developing adequate processing and labels and developing collective organisation for the marketing of those products; (6) Facilitate the installation of new entrants into farming by examining the specific set of conditions they are subject to and tailoring intervention to their needs and; (7) Perpetuate the VALAB initiative by fostering further collaborative partnerships with relevant actors within the innovation ecosystem and implement innovative approaches such as living laboratories.

\section{Discussion}

Sustainability challenges faced by forest farmers

The farmers highlighted a broad range of challenges spanning from the production to the commercialisation of forest farming products. The diversity and range of those challenges and the presence of a number of technical challenges amongst them (ex: lack of socio-technical references, lack of adequate mechanisation) is indicative of the lack of provision for forest farming in the current innovation system. Those challenges miror those faced by vanilla farmers in countries from the greater Caribbean such as Mexico, Costa Rica and Colombia: important knowledge gaps on the ecology, ecophysiology, agronomy and genetics of vanilla, lack of appropriate innovation infrastructure to support the development of the crop from the production to the commercialisation stages including technical training and advisory services (Borbolla-Perez et al. 2017; Flanagan and MosqueraEspinosa 2016; Azofeifa-Bolanos et al. 2014). Similarly to those countries, challenges arose in relation to the right balance to be achieved between agricultural production and conservation of genetics resources and biodiversity at the territorial scale (Watteyn et al. 2020; Flanagan and Mosquera-Espinosa 2016; Velazquez-Rosas et al. 2018). In order to address those challenges, farmers have, through the VALAB project (Integrated Value-enhancement of the Guadeloupean Forest Agrobiodiversity), opted for a renewed vision of the forest in the Guadeloupean context, a multifunctional vision that they defined at different levels. Their vision calls for an integrated development plan for agroforestry based on renewed approaches and moving away from previous sectoral orientations.

The workshops, through bringing together stakeholders whose farming systems are not mainstream, have enabled the identification of the specific constraints of this type of land use and allowed the expression of otherwise unheard voices (Faysse 2006; Bock 2012). They have revealed the importance of technical barriers in relation to crop production, shade management and protection of the environement. Those barriers, if removed, could enhance the productivity of the forest gardens while ensuring that the ecological functionality of the forest is preserved. The focus should be made on the quality of the forest farming products and the sustainability of associated agroforestry practices.

Towards the integrated value-enhancement of the Guadeloupean forest agrobiodiversity (VALAB): envisioning multifunctional forest gardens

Our results show that, in the relative absence of a proper innovation system for forest farming in Guadeloupe, reviewing existing experiences in different contexts while integrating local stakeholders' views and experience is key to the co-design of environmentally, economically, socially culturally appropriate forest gardens. Farmers' willingness to reconcile productive and conservation objectives should be the entry point for a reflection about a Stewardship status that would grant them the technical 
and ecological knowledge and capabilities to operate those farming systems at equilibrium.

Indeed, at the level of the cropping system, farmers referred to the model of the forest garden, a type of agroecosystem that comprises a wide diversity of crops associated temporally and spatially and an 'intermediate land-use system in the nature-culture continuum' which has yet to receive attention in agroforestry research (Wiersum 2004). This deficit of knowledge is also true of the Guadeloupean context were very few studies ( 8 references returned by a literature search on Web of Science with the following search strings: 'agroforestry and Guadeloupe' and 'forest cultivation and Guadeloupe') have been conducted on agroforestry systems. Those studies focused on very specific systems (i.e. swamp forests and tree plantation in pastures) that do not reflect the reality of participants as evidenced by Dominici (2016), CastroNunez (2018) and Rivière (2017). Examples of forest gardens have been reported in Indonesia (Mulyoutami et al. 2009). Their sustainability is ensured by specific governance arrangements that prevent their overexploitation, a question at the heart of future developments of forest farming in Guadeloupe and emphasized by the farmers when referring to achieving the joint objectives of agricultural production and protection of the natural environment. Other approaches to ensure the equilibrium of those agroecosystems have been suggested: Watteyn et al. (2020) recommend a strategy combining land sharing and land sparing; Velazquez-Rosas et al. (2018) associate ecological study and valorisation of traditional ecological knowledge to co-design agroforestry systems and, Flanagan et al. (2016) recommend a mix of participatory conservation strategies (in situ, ex situ and Circa situm, see p. 212) to be carried out with local communities. Review of those approaches, their adequacy and adaptability to the Guadeloupean context will need to be caried out.

At the farming system level, participants envisioned their farms as providing a wide range of ecosystem services beyond mere production. Indeed, by referring to agritourism or education, the desired futures supported the idea of the farms being vectors of cultural values and heritage and 'future farms' were meant to meet educational and cultural aspirations. This highlights the importance of diversifying beyond crop production and into new activities that could become part of farmers' livelihoods. If on-farm diversification has been extensively addressed in the literature, relatively few studies have analysed diversification of forest farms. Existing studies focus on understanding the determinants of forest farm diversification using comprehensive frameworks (Yang et al. 2018) or understanding the link between diversification and household welfare (Hong et al. 2019). Six recent references focus on characterising agroforestry in Guadeloupe, testifying the relative novelty of the topic and therefore of the knowledge gaps to be addressed (Castro Nunez 2018; Chaigneau 2018; Cheval 2018; Dominici 2016; Kiki 2015; Rivière 2017). Finally, farmers saw themselves as part of those forest gardens with a key role in ensuring the balance between agricultural production, protection of the environment and biodiversity conservation. They also wanted to play an active role in ensuring that a preserved heritage would be passed on to the next generation. They specified human-environment relationships, their connectedness with nature and stressed the importance of the resilience of socio-ecological systems. This is consistent with Sarkki et al. (2019)'s research explaining how human values can be both catalysts and consequences of social innovations and Melnykovych et. al (2018)'s research on adaptive responses of forest-dependent communities. Early inclusion of local stakeholders' voices is key to the success of conservation initiatives as it ensures potential conflicts around natural resources are handled efficiently, trade-offs between multiple objectives are achieved and natural resources sustainably managed (Agrawal et al. 2008; Larson and Soto 2008). This approach has been recommended as likely to support the sustainable use and conservation of vanilla resources in agroforestry systems in Colombia (Flanagan et al. 2016) and Mexico (Velazquez-Rosas et al. 2018). As such, building upon farmers' willingness to embrace a stewardship role is relevant and should be the entry point for any further development of agroforestry in Guadeloupe. It would help designing sustainable options for the management of ecosystems, as has been demonstrated in other contexts e.g. for the design and implementation of payments for ecosystem services (Kwayu et al. 2014; Poppenborg and Koellner 2013; Silvano et al. 2005; Zanella et al. 2014).

Next, farmers referred to and defined the heritage they wanted to pass on to the next generation. Current forest landscapes in Guadeloupe result from the 
historical interactions between forest and human beings that have shaped them (Demené 2014; Lassere 1961). As such, the 'Jardin des Hauts', a historical form of traditional forest gardens, comprised a wide range of species (coffee, cocoa, vanilla, medicinal plants, tubers...) which arrangement and usage were sustained by traditional ecological knowledge, knowhows and social values (Lassere 1961). Recovering those would represent an asset in designing sustainable, agroecological forest gardens that favour biodiversity conservation and ensure ecosystem services provision. This is in line with the early work of Thapa and Sinclair (1995) incorporating local knowledge in agroforestry development and more recently with Velazquez-Rosas et al.'s study (2018) who found traditional ecological knowledge to be a very valuable resource in co-designing vanilla agroforestry systems that are environmentally, economically and socially viable as well as culturally appropriate ad contributing to reinforcing the local identity.

Renewing the approach to innovation in agroforestry: innovation pathways bridging between sectors, actors and scales of governance

Our results highlight that in order to implement such vision of the multifunctionality of forest gardens, it is crucial to adopt a renewed paradigm of innovation at the local level and foster innovation pathways that not only bridge the gap between the agricultural and forestry sectors but also between actors and scales of governance. The approach needs to be systemic and inclusive, to recognise the diversity of actors shaping forest gardens and to propose agreed governance tools that define the roles and responsibilities of those actors.

The diversity of innovation pathways identified is coherent with the current degree of development of agroforestry in Guadeloupe. The analysis of the current and future desired situations not only indicates the lack of an adequate system of innovation for multifunctional agroforests (see Sect. 4.1.), but also represents a radical alternative to what has been proposed in terms of research and development for the past decades. Indeed, while historically, the Guadeloupean forest used to comprise multi-specific forest gardens ('Jardin des Hauts') of which traces remain (Larade, personal communication), research and development programmes in the past decades have focused on single-crop and sectoral development of vanilla, coffee and cocoa (SYAPROVAG, personal communication). The 'Jardin des Hauts' have a symbolic value that is that of a 'blessed time' and corresponds to a period when Guadeloupe used to produce quantities of high value-added export commodities and had established a reputation based on the quality of those products. The workshops we organized have highlighted the failure of a sectoral approach and pointed towards one that is tailored to the characteristics of the territory and builds upon the understanding of how the 'Jardin des Hauts' could be adapted to current socio-economic conditions and made coherent with modern lifestyles.

The experience of the participants suggests the need to move away from a sectoral approach and build towards the enabling of sustainable human-environment relationships. This is coherent with the objectives set out it the National Plan for the Development of Agroforestry that recognises the specificities of agroforestry systems in the French Overseas Department as well as the necessity to characterize them better (Ministère de l'Agriculture de l'Agroalimentaire et de la Forêt 2016). This is also in line with van Noordwijk et al. (2018), who consider agroforestry as a comprehensive land use that enables synergies between production and conservation and an opportunity to transcend current sectorial views on agriculture and forestry.

The barriers identified were not only of different natures but intervened at different scales, indicating that the problem to be solved is complex and requires a systemic approach. The solutions belonged to different dimensions and suggested different types of innovations: technical, organisational, market, social or institutional innovations. For example, the stewardship role farmers are willing to embrace could be acknowledged by a Stewardship status granted upon compliance to good management principles of the forest outlined in a Charter of good practices. Those practices would have, at the core the preservation of the different functions of the forest. The status could be financed by an innovative funding scheme based on agreement between public and private actors (ex: airlines companies offsetting their carbon emission by contributing to the scheme). In terms of social innovation, farmers could formally engineer the transmission of local ecological knowledge to the 
general public through for example demonstration on site of the process of vanilla production.

The various solutions identified imply working with different actors within the innovation system (farmers, researchers, development agents, traders, final consumers) and at different levels, while reaching out to institutional and policy actors. In addition, as evidenced by farmers' vision of the multifunctionality of agroforests, there is a need to adopt a socioecological approach to designing sustainable trajectories of the Guadeloupean forest. Pigford et al. (2018) suggest moving beyond the agricultural innovation system perspective towards an innovation ecosystem thinking. While the former allows an understanding of the complexity of agricultural innovation, considering it a result of co-learning processes, and intends to achieve institutional change and foster innovation capacity (Klerkx et al. 2012), the latter recognises the role of human and non-human change agents in shaping sustainable trajectories, and acknowledges multiple boundaries (Pigford et al. 2018). Similarly, Coe et al. (2014, p.76) call for a renewed agroforestry paradigm advocating for 'horizontal integration' across sectors and 'vertical integration' of national, regional, and local scales of governance and of field, farm and landscape scales of operation. The Valab operational group, as a multi-actors platform has initiated such a paradigm change by not only bringing together a diversity of actors with complementary visions, skills and expertise but also by innovating in terms of innovation and innovation governance processes (Barlagne et al., forthcoming). To be able to achieve its ambition and create long lasting legacy this platform needs to be institutionalised and embeeded in the current innovation system while preserving its original mode of operation caracterised by social innovation, social learning and co-construction processes.

\section{Conclusion}

Inclusion of stakeholders' voices in innovation processes is key to the design of sustainability transitions. This research aims to demonstrate that social innovation is a key component to innovation in agriculture and forestry and that by actually including stakeholders' views and experiences from the onset of an innovation process, we are able to learn from past failures and to identify new sustainable options more aligned to the local context. We conducted two participatory workshops with 18 farmers involved in a European Innovation Partnership Operational Group, a solution-oriented multi-actors platform promoted by the European Union, to identify their ambition, vision, values and barriers to implementing sustainable agroforestry systems. This work has revealed the challenges faced by farmers. The strategy identified, and to be implemented to overcome current challenges, ramified in a diversity of pathways which ranged from the production to the commercialisation stages, and including organisational and institutional matters. Participants embraced a multifunctional vision of the forest lanscape and saw themselves as part of the socio-ecological system towards which they have a duty. Their vision was one of harmonious and cohesive human-nature relationships. The participants have formulated a moral contract with future generations specifying what they considered to be their 'heritage' and what they wanted and did not want to pass on to the future generations. The participatory process sets the primary building blocks toward a reflection about the system of innovation for the future of agroforestry in Guadeloupe. Key recommendations are to bridge the gap between the agricultural and forestry sectors but also between actors and scales of governance. A Stewardhsip status should be developed and implemented building upon farmers' willingness to play an active role in the sustainable management of forest gardens. Finally, in order to maximise the benefits of such stakeholders' engagement in the design of sustainability transitions and create long lasting legacy, the platform needs to be embeeded in the current innovation ecosystem while preserving its original mode of operation. Future research is foreseen on the policy conditions for the existence of such Stewardship status as well as on the model of innovation that arise from such platforms.

Acknowledgements The authors are greatful to the European Commission for its support of the project on Social Innovation in Marginalized Rural Areas (SIMRA, www.simra-h2020.eu) provided from the European Union's Horizon 2020 Research and Innovation Programme under Grant Agreement No 677622 and for its support on the Integrated Ecosystemic Value enhancement of the Guadeloupean Forest Agrobiodiversity (VALAB, https://ec.europa.eu/eip/agriculture/sites/agri-eip/ files/2019-ws-small_is_smart_booklet_final.pdf) provided from the European Agricultural Fund for Rural Development under the Rural Development Program Guadeloupe under Grant 
Agreement $\mathrm{N}^{\circ}$ 2014FR06RDRP001. This research was also partly funded by the Rural \& Environment Science \& Analytical Services Division of the Scottish Government through its Strategic Research Programme (2016-2021). Special thanks go to the participants to the workshops for their time and inputs into the research, to the two anonymous reviewers and to Michaela Roberts and Nathalie Cialdella for the revision of this paper. They also wish to thank Orla Shortall, Alba Juares Bourke and Adrian Budnik for language editing, Douglas Wardel Johnson for the production of visuals and Alexandre Aquilon for the photographs taken.

Data availability The datasets generated and analysed during the current study are not publicly available due to compliance with the research ethics and further use of the project but are available from the corresponding author on reasonable request.

\section{Declarations}

Conflict of interest The authors declare that they have no conflicts of interest.

Human and animal participants The research has involved Human participants. The research has been reviewed by The James Hutton Institute Research Ethics Committee which has approved the research plan and all activities included.

Informed consent Participants have been informed of the purpose of the research and have been given the opportunity to ask questions and withdraw from the study in which case their data would not be used. All participants included in the study gave informed consent to their data and image being used for the purpose of the research and publications.

Open Access This article is licensed under a Creative Commons Attribution 4.0 International License, which permits use, sharing, adaptation, distribution and reproduction in any medium or format, as long as you give appropriate credit to the original author(s) and the source, provide a link to the Creative Commons licence, and indicate if changes were made. The images or other third party material in this article are included in the article's Creative Commons licence, unless indicated otherwise in a credit line to the material. If material is not included in the article's Creative Commons licence and your intended use is not permitted by statutory regulation or exceeds the permitted use, you will need to obtain permission directly from the copyright holder. To view a copy of this licence, visit http://creativecommons.org/licenses/by/4.0/.

\section{References}

Adams WM et al (2004) Biodiversity conservation and the eradication of poverty. Science 306:1146-1149. https:// doi.org/10.1126/science. 1097920

Agrawal A, Chhatre A, Hardin R (2008) Changing governance of the world's forests. Science 320:1460-1462. https://doi. org/10.1126/science.1155369
Azofeifa-Bolaños J, Paniagua-Vasquez A, García-García J (2014) Importancia y desafíos de la conservación de Vanilla spp. (Orquidaceae) en Costa Rica. Agron Mesoam 25:189-202. https://doi.org/10.15517/am.v25i1.14220

Barlagne CV, Marini Govigli MN, Miller D (forthcoming). Beyond interactive innovation: the potential of social innovation in reshaping innovation processes in agriculture and forestry

Bock BB (2012) Social innovation and sustainability; how to disentangle the buzzword and its application in the field of agriculture and rural development. Stud Agricul Econ (budapest) 114:57-63

BEPA (2012) Challenge Social Innovation. In: Hans-Werner F, Hochgerner J (eds) Challenge social innovation: potentials for business, social entrepreneurship, Welfare and Civil Society

SpringerLink : Bücher. illustrated edn. Springer Science \& Business Media, 2012, Springer Heidelberg New York Dordrecht London, p 386

Borbolla-Pérez V, Iglesias-Andreu LG, Luna-Rodríguez M, Octavio-Aguilar P (2017) Perceptions regarding the challenges and constraints faced by smallholder farmers of vanilla in Mexico environment. Dev Sustain 19:2421-2441. https://doi.org/10.1007/s10668-016-9863$\mathrm{y}$

Burgess PJ, Rosati A (2018) Advances in European agroforestry: results from the AGFORWARD project. Agrofor Syst 92:801-810. https://doi.org/10.1007/s10457-0180261-3

Castro Nunez T (2018) Entre tradition et innovation: diagnostic socio-économique des agrosystèmes en sous-bois de Guadeloupe. Université Toulouse III Paul Sabatier, Etude exploratoire pour la valorisation $\mathrm{du}$ sous-bois guadeloupéen

Chaigneau R (2018) Identification, caractérisation et évaluation des systèmes de culture en sous-bois de Guadeloupe. Mémoire de fin d'études. VetAgro Sup et Montpellier SupAgro, p 112

Cheval A (2018) Quelle place pour l'élevage dans la valorisation des sous-bois de Guadeloupe? ISTOM, p 93

Coe R, Sinclair F, Barrios E (2014) Scaling up agroforestry requires research 'in' rather than 'for' development. Curr Opin Environ Sustain 6:73-77. https://doi.org/10.1016/j. cosust.2013.10.013

Cubbage F et al (2012) Comparing silvopastoral systems and prospects in eight regions of the world. Agrofor Syst 86:303-314. https://doi.org/10.1007/s10457-012-9482-z

de Souza HN et al (2012) Learning by doing: a participatory methodology for systematization of experiments with agroforestry systems, with an example of its application. Agrofor Syst 85(2):247-262

Demené C (2014) Entre nature et agriculture. Agricultures patrimoniales et services environnementaux en aire d'adhésion des parcs nationaux à la Réunion et en Guadeloupe. Université de la Réunion, p 512

Dominici T (2016) Valorisation du sous-bois en Guadeloupe pour l'agriculture: comment concilier production et protection? ISTOM, p 99

Dulormne M, Sierra J, Nygren P, Cruz P (2003) Nitrogen-fixation dynamics in a cut-and-carry silvopastoral system in the subhumid conditions of Guadeloupe. French Antilles 
Agrofor Syst 59:121-129. https://doi.org/10.1023/a: 1026387711571

Faysse N (2006) Troubles on the way: An analysis of the challenges faced by multi-stakeholder platforms. Nat Res Forum 30:219-229. https://doi.org/10.1111/j.1477-8947. 2006.00112.x

Fedrigo JK, Santa Cruz R, Benítez V, Courdin V, Ferreira G, Posse JP, Viñoles C (2018) Dynamics of forage mass, air temperature and animal performance in a silvopastoral system of Uruguay. Agrofor Syst. https://doi.org/10.1007/ s10457-018-0335-2

Flanagan N, Mosquera-Espinosa A (2016) An integrated strategy for the conservation and sustainable use of native vanilla species in Colombia. Lankesteriana 16:201-218. https://doi.org/10.15517/lank.v16i2.26007

Foley JA et al (2011) Solutions for a cultivated planet. Nature 478:337-342. https://doi.org/10.1038/nature10452

Geoffroy A, Sanguin H, Galiana A, Ba A (2017) Molecular characterization of Arbuscular Mycorrhizal fungi in an agroforestry system reveals the predominance of Funneliformis spp. Assoc Coloca Escul Pterocarpus off Adult Trees Seedl Front Microbiol 8:10. https://doi.org/10.3389/ fmicb.2017.01426

Glamann J, Hanspach J, Abson DJ, Collier N, Fischer J (2017) The intersection of food security and biodiversity conservation: a review. Reg Envir Chang 17:1303-1313. https:// doi.org/10.1007/s10113-015-0873-3

Haxeltine A et al. (2016) A framework for transformative social innovation (TRANSIT Working Paper \#5)

Hewitt RJ, Hernandez-Jimenez V, Zazo-Moratalla A, OcónMartín B, Román-Bermejo L, Encinas-Escribano MA (2017) Participatory modelling for resilient futures: action for managing our environment from the bottom-up. Elsevier Science

Hong Y-Z, Liu W-P, Dai Y-W (2019) Income diversification strategies and household welfare: empirical evidence from forestry farm households in China. Agrofor Syst 93:1909-1925. https://doi.org/10.1007/s10457-018-03000

Imbert D, Saur E, Bonheme I, Roseau V (2004) Traditional taro (Colocasia esculenta) cultivation in the swamp forest of Guadeloupe (F.W.I.): impact on forest structure and plant biodiversity. Revue D'ecol (terre Vie) 59:181-189

Khadka C, Aryal KP, Edwards-Jonášová M, Upadhyaya A, Dhungana N, Cudlin P, Vacik H (2018) Evaluating participatory techniques for adaptation to climate change: Nepal case study. Forest Policy Econ 97:73-82. https://doi. org/10.1016/j.forpol.2018.08.017

Kiki S (2015) Etude des filières café et cacao de Guadeloupe. DAAF Guadeloupe

Klerkx L, van Mierlo B, Leeuwis C (2012) Evolution of systems approaches to agricultural innovation: concepts, analysis and interventions. In: Darnhofer I, Gibbon D, Dedieu B (eds) Farming systems research into the 21st century: The new dynamic. Springer Netherlands, Dordrecht, pp 457-483. doi:https://doi.org/10.1007/978-94-0074503-2_20

Kwayu EJ, Sallu SM, Paavola J (2014) Farmer participation in the equitable payments for watershed services in Morogoro. Tanzania Ecosyst Serv 7:1-9. https://doi.org/10. 1016/j.ecoser.2013.12.006
Lasserre G (1961) La Guadeloupe, étude géographique. I. La nature et les hommes Bordeaux, UFI

Larson AM, Soto F (2008) Decentralization of natural resource governance regimes. Annu Rev Environ Resour 33:213-239. https://doi.org/10.1146/annurev.environ.33. 020607.095522

MacCallum D, Haddock SV, Moulaert F (2016) Social innovation and territorial development. Taylor \& Francis

Marini Govigli V, Alkhaled S, Arnesen T, Barlagne C, Bjerck M, Burlando C, Melnykovych M, Rodríguez FernandezBlanco C, Sfeir P, Górriz-Mifsud E (2020) Testing a framework to co-construct social innovation actions: insights from seven marginalized rural areas. Sustainability 12(4): 1441

MEA (2005) Ecosystems and human well-being: current state and trends: findings of the condition and trends working group. Island Press

Melnykovych M, Nijnik M, Soloviy I, Nijnik A, Sarkki S, Bihun Y (2018) Social-ecological innovation in remote mountain areas: adaptive responses of forest-dependent communities to the challenges of a changing world. Sci Total Environ 613-614:894-906. https://doi.org/10.1016/j.scitotenv. 2017.07.065

Minang PA, van Noordwijk M, Freeman OE, Mbow C, de Leeuw J, Catacutan D (2014) Climate-smart landscapes: multifunctionality in Practice. World Agroforestry Centre

Ministère de l'Agriculture de l'Agroalimentaire et de la Forêt (2016) Plan de développpement de l'agroforesterie. Pour le développement et la gestion durable de tous les systèmes agroforestiers

Mulyoutami E, Rismawan R, Joshi L (2009) Local knowledge and management of simpukng (forest gardens) among the Dayak people in East Kalimantan, Indonesia. Forest Ecol Manag 257:2054-2061. https://doi.org/10.1016/j.foreco. 2009.01.042

Myers N, Mittermeier RA, Mittermeier CG, da Fonseca GAB, Kent J (2000) Biodiversity hotspots for conservation priorities. Nature 403:853-858. https://doi.org/10.1038/ 35002501

Nair PKR (1987) Agroforestry systems inventory. Agrofor Syst 5:301-317. https://doi.org/10.1007/bf00119128

Neumeier S (2012) Why do social innovations in rural development matter and should they be considered more seriously in rural development research? - Proposal for a stronger focus on social innovations in rural development research. Soc Rural 52:48-69. https://doi.org/10.1111/j. 1467-9523.2011.00553.x

Nijnik M, Secco L, Miller D, Melnykovych M (2019) Can social innovation make a difference to forest-dependent communities? Forest Policy Econ 100:207-213. https://doi.org/ 10.1016/j.forpol.2019.01.001

Pantera A et al (2018) Agroforestry for high value tree systems in Europe. Agrofor Syst 92:945-959. https://doi.org/10. 1007/s10457-017-0181-7

Persha L, Agrawal A, Chhatre A (2011) Social and ecological synergy: local rulemaking, forest livelihoods, and biodiversity conservation. Science 331:1606-1608. https://doi. org/10.1126/science. 1199343

Pigford A-AE, Hickey GM, Klerkx L (2018) Beyond agricultural innovation systems? Explor Agricul Innov Ecosyst 
Approach Niche Des Dev Sustain Trans Agricul Syst 164:116-121. https://doi.org/10.1016/j.agsy.2018.04.007

Polman N, Slee B, Kluvankova T, Dijkshoorn M, Nijnik M, Gezik V, Soma K (2017) Classification of social innovations for marginalized rural areas. SIMRA

Poppenborg P, Koellner T (2013) Do attitudes toward ecosystem services determine agricultural land use practices? An Anal Farmers' Decis Mak South Korean Watershed Land Use Policy 31:422-429. https://doi.org/10.1016/j. landusepol.2012.08.007

Power AG (2010) Ecosystem services and agriculture: tradeoffs and synergies. Philos Trans Royal Soc b Biol Sci 365:2959-2971

Prabhu R, Sinclair F, Vanclay J (2012) Realizing community futures: a practical guide to harnessing natural resources. Taylor \& Francis

Reed MS (2008) Stakeholder participation for environmental management: a literature review. Biol Cons 141:2417-2431. https://doi.org/10.1016/j.biocon.2008.07. 014

Rivière M (2017) Développement de l'agroforesterie ultra-marine. Etat des lieux de l'agroforesterie et réflexions sur l'application du Plan de Développement de l'Agroforesterie dans les Départements d'Outre-Mer. AgroParisTech

Sarkki S et al (2019) Human values as catalysts and consequences of social innovations. Forest Policy Econ 104:33-44. https://doi.org/10.1016/j.forpol.2019.03.006

Sayer J et al (2013) Ten principles for a landscape approach to reconciling agriculture, conservation, and other competing land uses. Proc Natl Acad Sci 110:8349-8356. https://doi. org/10.1073/pnas.1210595110

Schut $M$ et al (2015) RAAIS: rapid appraisal of agricultural innovation systems (Part I). A Diag Tool IntegrAnal Complex Prob Innov Capac Agricul Syst 132:1-11. https:// doi.org/10.1016/j.agsy.2014.08.009

Scoones I, Thompson J (2009) Farmer first revisited: innovation for agricultural research and development. Practical Action Pub

Sierra J, Daudin D (2010) Limited $15 \mathrm{~N}$ transfer from stemlabeled leguminous trees to associated grass in an agroforestry system. Eur J Agron 32:240-242. https://doi.org/ 10.1016/j.eja.2009.11.003

Silvano RAM, Udvardy S, Ceroni M, Farley J (2005) An ecological integrity assessment of a Brazilian Atlantic Forest watershed based on surveys of stream health and local farmers' perceptions: implications for management. Ecol Econ 53:369-385. https://doi.org/10.1016/j.ecolecon. 2004.12.003

SIMRA (2016) Social innovation in marginalised rural areas grant proposal. European Union

Smith A, Seyfang G (2013) Constructing grassroots innovations for sustainability. Glob Environ Chang 23:827-829. https://doi.org/10.1016/j.gloenvcha.2013.07.003

Sunderland TCH, Ehringhaus C, Campbell BM (2007) Conservation and development in tropical forest landscapes: a time to face the trade-offs? Environ Conserv 34:276-279. https://doi.org/10.1017/S0376892908004438

Sunderlin WD, Angelsen A, Belcher B, Burgers P, Nasi R, Santoso L, Wunder S (2005) Livelihoods, forests, and conservation in developing countries: an overview. World Dev 33:1383-1402. https://doi.org/10.1016/j.worlddev. 2004.10.004

Tabora PC (1991) Analysis and evaluation of agroforestry as an alternative environmental design in the Philippines. Agrofor Syst 14:39-63. https://doi.org/10.1007/ bf00141596

Thapa B, Sinclair FL, Walker DH (1995) Incorporation of indigenous knowledge and perspectives in agroforestry development. Agrofor Syst 30:249-261. https://doi.org/10. 1007/BF00708924

Torres B, Vasco C, Gunter S, Knoke T (2018) Determinants of agricultural diversification in a hotspot area: evidence from Colonist and indigenous communities in the Sumaco biosphere reserve. Ecuad Amazon Sustain 10:21. https://doi. org/10.3390/su10051432

United Nations Development Programme (2015) Sustainable development goals

USDA (2019). Forest Farming. National agroforestry center website. https://www.fs.usda.gov/nac/practices/forestfarming.php. Accessed 22 June 2021

van Noordwijk M et al (2018) SDG synergy between agriculture and forestry in the food, energy, water and income nexus: Reinventing agroforestry? Curr Opin Environ Sustain 34:33-42. https://doi.org/10.1016/j.cosust.2018.09.003

Velázquez-Rosas N, Silva-Rivera E, Ruiz-Guerra B, ArmentaMontero S, Trejo González J (2018) Traditional ecological knowledge as a tool for biocultural landscape restoration in northern Veracruz, Mexico: a case study in El Tajín region ecology and society 23 . https://doi.org/10.5751/ES-10294230306

Watteyn C, Fremout T, Karremans A, Huarcaya R, Bolaños J, Reubens B, Muys B (2020) Vanilla distribution modeling for conservation and sustainable cultivation in a joint land sparing/sharing concept. Ecosphere. https://doi.org/10. 1002/ecs 2.3056

Wiersum KF (2004) Forest gardens as an 'intermediate' landuse system in the nature-culture continuum: characteristics and future potential. In: Nair PKR, Rao MR, Buck LE (eds) New vistas in agroforestry: a compendium for 1st World congress of agroforestry, 2004. Springer Netherlands, Dordrecht, pp 123-134. doi:https://doi.org/10.1007/97894-017-2424-1_9

Yang L, Liu M, Min Q, Li W (2018) Specialization or diversification? The situation and transition of households' livelihood in agricultural heritage systems. Int J Agricul Sustain 16:455-471. https://doi.org/10.1080/14735903. 2018.1537669

Zanella MA, Schleyer C, Speelman S (2014) Why do farmers join payments for ecosystem services (PES) schemes? An assessment of PES water scheme participation in Brazil. Ecol Econ 105:166-176. https://doi.org/10.1016/j. ecolecon.2014.06.004

Publisher's Note Springer Nature remains neutral with regard to jurisdictional claims in published maps and institutional affiliations. 